\title{
An International Comparison of Nongovernmental Education Research Agencies
}

\author{
Sheng Yao Cheng ${ }^{\mathrm{a}, *}$

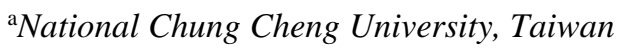

\begin{abstract}
Since the early 1990s, nations like the United Kingdom and the United States and multilateral organizations like UNESCO and OECD were looking forward to promoting the quality of education research and linking bridges among education research, education policies, and schooling. The principal investigator focuses on the issues associated with nongovernmental education research agencies with a goal to improve the construction of nongovernmental education research agencies in Taiwan. To overcome the research purposes we mentioned in the beginning, the researcher collects an extensive literature review related to education research agencies, education research policies, education research quality indicators, and schooling first. Moreover, the author aims at the issue related to nongovernmental education research agencies in eight case countries or international organizations to analyze the problems and struggles along with education research policies, education research quality indicators, and education practice via field study and in-depth interview data collection methods in each case country. Finally, the researcher juxtaposes and compares the development and models of nongovernmental research agencies in the world along with current issues in Taiwan. By conducting a series of focus group discussion panels on the issues of nongovernmental research agencies, the researcher reflects on the recent situation of nongovernmental research agencies with the interaction among education research, education research policies, education research quality indicators, and education practices, and provide some suggestions for future strategic plans on the development of nongovernmental research agencies and education research in Taiwan.
\end{abstract}

\begin{abstract}
Abstrak
Sejak awal tahun 1990, negara-negara seperti Inggris dan Amerika Serikat, serta organisasi multilateral seperti UNESCO dan OECD, telah berupaya meningkatkan kualitas penelitian pendidikan dan menjembatani penelitian dengan kebijakan pendidikan dan sekolah. Penelitian ini difokuskan pada lembaga non-pemerintah atau LSM yang melakukan penelitian bidang pendidikan, dengan harapan dapat memperbaiki model LSM penelitian pendidikan di Taiwan. Untuk mencapai tujuan ini, peneliti terlebih dahulu mengumpulkan banyak kajian literatur tentang LSM penelitian pendidikan, kebijakan penelitian pendidikan, indikator kualitas penelitian pendidikan, dan kebijakan sekolah. Kemudian, penulis menyoroti beberapa permasalahan LSM penelitian pendidikan di delapan negara atau beberapa organisasi internasional, guna menganalisa problematika dan kendala mereka terkait dengan kebijakan penelitian pendidikan, indikator kualitas penelitian pendidikan, dan praktek pendidikan. Pengumpulan data dilakukan melalui studi lapangan dan wawancara mendalam untuk masing-masing negara. Kemudian peneliti membandingkan perkembangan dan model LSM penelitian di dunia, termasuk tren terkini di Taiwan. Melalui serangkaian panel diskusi fokus kelompok, peneliti mengkaji situasi terkini LSM penelitian, kaitannya dengan penelitian pendidikan, kebijakan penelitian pendidikan, indikator kualitas penelitian pendidikan dan praktik pendidikan. Penelitian ini menawarkan beberapa saran dan rencana strategis ke depan untuk pengembangan LSM penelitian pendidikan dan isu penelitian pendidikan di Taiwan.
\end{abstract}

Keywords: Education Research, Education Research Policy, Education Research Quality, Nongovernmental Research Agencies, Taiwan,

\section{Introduction}

Teacher education is a major tool governments all over the world rely on to deal with global and regional socialization and workforce development (Lauder 2006; Spivak, 2012). How to conduct effective educational research that can help foster and guide appropriate

*Corresponding author. Address: National Chung Cheng Unieducation policies leading to positive practices is a national and 
nongovernmental organization (NGO) priority in the twenty-first century (Stedman 1985; Green 1997; Committee on Education and the Workforce 2012).

However, along with increased resources allocated to educational research from public, private, and nongovernmental sectors, there is also an increase in the connections among educational research agencies, policies, practices on accountability, and social reforms. For instance, in 1958, the National Research Council (NRC) drafted “A Proposed Organization for Research in Education” to suggest that the federal government establish an organization to monitor the quality of educational research in the United States (NRC 1958). In its What Works in Education? report, the RAND Corporation argued that educational research budgets in the United States did not generally allocate funding to discover and articulate professional knowledge in the field of education and schooling (President's Commission on School Finance 1971). In 1972, Averch and colleagues (1972) claimed that most of the findings of current educational research could not provide "continuous" and "strict” evidence to improve the quality of students' learning.

To address the critiques above, the U.S. federal government established the National Institute of Education (NIE) in 1972, and created the Office of Educational Research and Improvement (OERI) under the administration of the U.S. Department of Education in 1980. However, according to NRC’s (1999) strategic plan to outline purposes for education research and its utilization, the outcomes of educational research still relied too much on personal experiences and ideology. Furthermore, NRC also noted how education theories, research methods, and research design frameworks were either inadequate or not used appropriately.

Similar to the United States, in the United Kingdom, the Research Assessment Exercise (RAE) evaluated professional research communities in 1989 and found the education only scored 2.5 out of 5 , second from the bottom among academic fields assessed. In 2008, the educational research assessment score decreased to 2.4 (RAE 2009). Moreover, OECD (1995) and James Tooley (1998) concluded that the patchwork of knowledge in the field of educational research was generally without rigor in terms of research methods and establishing appropriate research design frameworks.

To interpret the issues outlined above, a group of senior education researchers based in Taiwan and the United States conducted a three-year integrated comparative study of the interactions of educational research among different nations, international organizations, and other research agencies. First, the investigators conducted an extensive literature review of what nongovernmental organizations (NGOs) are doing in relation to educational research, with specific focus devoted to analyzing institutional reports on educational research. Second, the investigators interviewed several experts to better understand the interactions between nongovernmental educational research and its overall quality. Based on this second focus, the authors interpret the interconnections among the educational research of NGOs, policies, and practices.

\section{The Quality of Education Research}

Stokes (1997) pointed out that scientific research could be divided into four quadrants according to the quest for fundamental understanding and the consideration of use (see Figure 1). If a scientific research study could take care of both fundamental understanding and consideration of use, Stokes called it use-inspired basic research. If a scientific research study only focused on the question of fundamental understanding and ignored the consideration of use, it was called pure basic research. If a study only kept an eye on the consideration of use and ignored the question of fundamental understanding, it was called pure applied research. If a study did not cover either of these two quests or considerations, it was not regarded as a scientific research study.

Figure 1. Scientific Research Models

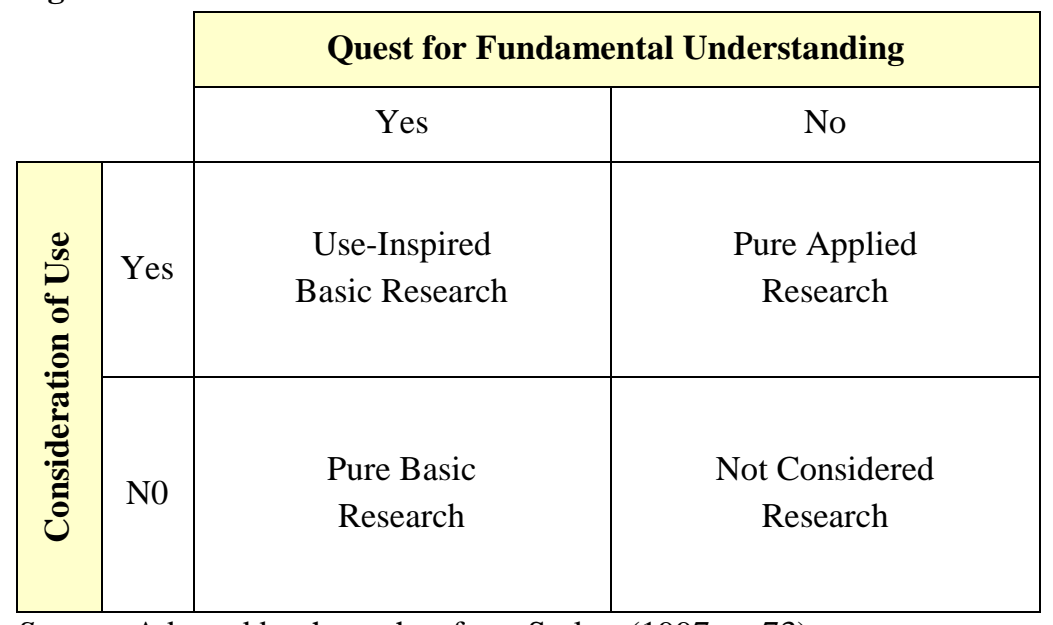

Source: Adapted by the author from Stokes (1997, p. 73).

Following this vein, how could we best define educational research? Should educational research belong to pure basic research, pure applied research, or use-inspired basic research? Based on the RAND Report (RAND 1971) and the connection between educational research and educational practice in the Educational Research and Development: Trends, Issues, and Challenges (OECD 1995), educational research should be as close as possible to the use-inspired basic research area outlined by Stokes.

In reference to the quality of educational research in the United States, the NRC produced two reports-(1) Fundamental Research and the Process of Education in 1977 to ensure the importance of educational basic research, and (2) Creating a Center for Education 
Statistics: A Time for Action in 1986 - to set up an educational organization to use federal educational Statistics. NRC also produced a report titled Research and Education Reform: Roles for the Office of Educational Research and Improvement to reflect on the mission of the federal government and the Office for Educational Research and Improvement and criticize many educational research projects as quick solutions to poorly understood problems (NRC 1992, p. viii).

In its Scientific Research in Education report in 2002, NRC provided further guidance about credible information in the field of education via rigorous and relevant educational research. Shortly afterwards, the US government legislated the Education Sciences Reform Act of 2002 (ESRA), discontinued the OERI, and established the Institute of Education Sciences (IES) (NRC 2002).

According to the NRC (2002, pp. 3-5), there are six principles that should be included in all educational research initiatives:

1. Pose significant questions that can be investigated empirically,

2. Link research to relevant theories,

3. Use methods that permit direct investigation of the question,

4. Provide a coherent and explicit chain of reasoning,

5. Replicate and generalize across studies, and

6. Disclose research findings to encourage professional scrutiny and critique.

\section{NGOs and Educational Research}

Society can be interpreted as having three a distinct sector types: public sector, private sector, and non-profit sector (Berlie 2010; see Table 1). According to Kadzamira and Kunje (2002), NGOs are independent organizations separate from governmental cooperation. Jong Jun (1986, p. 117) identified six general features of most NGOs: (1) offer public services, (2) serve as a bridge between government and citizens, (3) provide direct services to their customers, (4) have flexible organizational structures, (5) open to learning about and accepting innovative and experimental ideas and programs, and (6) often play the role of public interest gatekeepers.

As of 2011, there were more than 40,000 NGOs in the United States, 277,000 NGOs in Russia, and 3,300,000 NGOs in India (Davaadorj 2011). With limited resources, education-oriented NGOs often tend to cooperate with governmental organizations via three different kinds of strategic alliances. The first kind is called horizontal strategic alliances, which stress similarities of backgrounds between governmental and nongovernmental organizations. Horizontal strategic alliances emphasize cooperation with equal educational inputs from both sides. Second, vertical strategic alliances, which outline the unequal relationship between governmental and nongovernmental organizations, where governmental organizations tend to be positioned above their NGO counterparts. The third is called quasi-vertical strategic alliances, which represent backgrounds and relationships between governmental and nongovernmental organizations that are in-between vertical and horizontal strategic alliances (Iqbal 2010; Kadzamira and Kunje 2002; Davaadorj 2011).

Table 1. Comparison Among Public, Private, and Nongovernmental Sectors

\begin{tabular}{|l|c|c|c|}
\hline & $\begin{array}{c}\text { Public } \\
\text { Sector }\end{array}$ & $\begin{array}{c}\text { Private } \\
\text { Sector }\end{array}$ & $\begin{array}{c}\text { Nongovernmental } \\
\text { Sector }\end{array}$ \\
\hline Philosophy & Social Justice & Profit & Non Profit \\
\hline $\begin{array}{l}\text { Financial In- } \\
\text { put }\end{array}$ & Tax & Commodity & Donation \\
\hline $\begin{array}{l}\text { Decision } \\
\text { Making }\end{array}$ & By law & Owner & Board Trustee \\
\hline Range & Wide & Customers only & Limited \\
\hline Administration & Bureaucratic & $\begin{array}{c}\text { Bureaucratic or } \\
\text { charter }\end{array}$ & $\begin{array}{c}\text { Small size of Bur- } \\
\text { eaucratic model }\end{array}$ \\
\hline Service & Constant & Changeable & Changeable \\
\hline Organizations & Large & Small to Large & Small \\
\hline
\end{tabular}

Source: Adapted by the author from Kramer (1987, p. 243).

After reviewing existing findings of NGOs, the principal investigator first outlines the non-governmental educational research agencies in the United States, European Union, and Australia in the existing literature. In the United States, research focused organizations include the American Educational Research Association (AERA), the Carnegie Foundation for the Advance-ment of Teaching, the RAND Corporation, the Rockefeller Foundation, and the Ford Foundation. The EU conducts a series of research studies on public, private, and research and technology organizations (RTOs) and divides the missions into basic research, applied research, development, certification/standards, diffusion/ extension, and provision of facilities (EURAB 2005). In Australia, the top education research NGOs include the Australian Council for Educational Research (ACER), the Australian Association for Research in Education (AARE), and the Western Australian Institute for Educational Research (WAIER).

\section{Analysis and Discussion}

Anthony Bryk, President of the Carnegie Foundation for the Advancement of Teaching and Professor at the College of Education at Stanford University, analyzes the quality of 
educational research in the United States and provides six meaningful findings:

1. Lack of sufficient educational research budget. Five to 15 percent of the total budget of the medical and mechanical engineering fields are allocated to Research and Development (R\&D), and 20 percent of the R\&D budget is allocated to support basic research, while the other 80 percent is used for design and systematic development. Unfortunately, the academic field of education could be seen as a big enterprise with a US\$500 million budget, but less than US\$1 million is used for R\&D, which is less than 0.25 percent.

2. Most educational research is conducted inside higher education institutions (HEIs). However, traditional HEIs value theories more than practices, so there is less incentive for college researchers to conduct education research on practical problems.

3. The practical wisdom of schooling should be learned from daily life, but practioners may lack research competency to translate this into professional knowledge.

4. Most school districts adopt short-term responsive models to implement teaching innovations.

5. Commercial sectors, including textbook and curriculum development and teacher professional development, do not play an important role in the field of educational research.

6. The financial suppport critieria from the federal and state governments distort the development of educational research. (Bryk and Gomez 2007, pp. 3-8)

Bryk’s (2008) critique of governmental educational research also pushes the development of nongovernmental educational research. According to Cheng (2013), nongovernmental educational research tends to focus on use-inspired pure research, purely appllied research, and purely basic research. The relationship between nongovernmental and governmental educational research organizations could be horizontal, vertical, or quasi-vertical, and they often depend on committed centralized and decentralized governments. Furrhermore, the European Commission plans to set up a European Research Area to encourage the cooperation of educational research agencies, foster innovative educational research ideas, educational research agency personnel, and leverage the capacities of researchers to increase the quality of educational research (European Commission 2011).

\section{Conclusion}

Regarding the issue of educational research quality, the publication of the Coleman Report in 1966 highlighted the interactions among studentss' performance, school budgets, curricula, and their parents' educational and social backgrounds. The Coleman Report had a huge impact on educational policies because the result was that some scholars have since argued that schools do not make a significant difference in student learning (Jencks et al. 1972).

After the Coleman Report, many educational researchers focused on how to provide valid evidence to prove that schools do matter (Loeb and Page 2000; Rutter 1982). Along with the discussion about effective teachers and high-performing schools, a series of educational researchers included the following as aspects of effective teaching: planning lessons carefully, selecting appropriate materials, making their goals clear to students, maintaining a brisk pace in lessons, checking students' work reguarly, and teaching the same material again when students have trouble learning (Cohen, Rqudenbush, and Ball 2002; Edmonds 1984; Stedman 1985).

The United States has a strong federal government, but educational policies and practices have historically been left to state and local governments, so that traditionally, the federal government has had a limited impact on educational policies and practices at the school district level. This has been the case until recent decades, when the balance shifted to federal intervention in educational policies nationwide. However, if we check the current Common Core movement in the United States, a centralized trend in the issues of a national crriculum and national testing have become the top priority (Cheng and Jacob 2015). How will nongovernmental educational research agencies face this new phenomenon as the federal government takes on this new role in educational research and practice? This is among the important follow-up research questions that the principal investigator plans to research next.

\section{References}

Australia Association for Research in Education (AARE). 2012. 2012 Annual Report of the Australia Association for Research in Education. Sydney: AARE.

Australian Council for Education Research (ACER). 2012. Annual Report 2011. Sydney: ACER.

Academy for Educational Development (AED). 2003. Partnerships in Education: Key Findings on the Role of NGOs in Basic Education in Africa. Washington, DC: AED. 
American Educational Research Association (AERA). 2011. Inciting the Social Imagination: Education Research for the Public Good. Paper presented at the 2011 AERA Annual Meeting Program, New Orleans, Louisiana.

Australian Education Council. 1994. A Statement on Technology for Australian Schools, A Joint Project of the States, Territories and the Commonwealth of Australia Initiated by the Australian Education Council. Carlton, Victoria: Curriculum Corporation.

Australian Government, and Australian Research Council. 2011. Excellence in Research for Australia 2010: National Report. Canberra: Australian Research Council.

Averch, Harvey A., Stephen J. Carroll, Theodore S. Donaldson, Herbert J. Kiesling, and John A. Pincus. 1972. How Effective Is Schooling? A Critical Review and Synthesis of Research Findings. Santa Monica, CA: RAND Corporation.

Berlie, Laurence S. 2010. Alliances for Sustainable Development: Business and NGO Partnerships. Basingstoke, UK; New York: Palgrave Macmillan.

Bryk, Anthony S. 2008. The Future of Education Research. Washington, DC: American Enterprise Institute.

Bryk, Anthony S., and Louis Gomez. 2007. "Ruminations on Reinventing an R\&D Capacity for Educational Improvement.” Paper presented at the American Enterprise Institute Conference, 25 October 2007.

Carnegie Foundation for the Advancement of Teaching. 2011. About Carnegie Foundation for the Advancement of Teaching. Stanford, CA: Carnegie Foundation for the Advancement of Teaching.

Cohen, David K., Stephen W. Rqudenbush, and Deborah L. Ball. 2003. "Resources, Instruction, and Research.” Educational Evaluation and Policy Analysis 25 (2): 119-142.

Coleman, James. S., Ernest Q. Cambell, Carol F. Hobson, James McParland, Alexander M. Mood, Frederic D. Weinfeld, and Robert L. York. 1966. Equality of Educational Opportunity. Washington, DC: U.S. Government Printing Office.

Committee on Education and the Workforce. 2012. Education Research Identifying Effective Programs to Support Students and Teachers: Hearing Before the Subcommittee on Early Childhood, Elementary and Secondary Education, Committee on Education and the Workforce, U.S. House of Representatives, One Hundred Twelfth Congress, first session. Hearing held in Washington, DC, 16 November 2011.

Davaadorj, Khulan. 2011. Voices of Non-Governmental Organizations on Education. New York: United Nations.

Dohmen, Dieter. 2011. Finanzierung und ökonomische Aspekte des Bildungsföderalismus. In Bildungsföderalismus und Bildungsfinanzierung, Berlin: Friedrich-Ebert-Stiftung.
Edmonds, Ronald. 1984. "School Effects and Teacher Effects.” Social Policy 15 (2): 37-29.

European Research Advisory Board (EURAB). 2005. Research and Technology Organisations (RTOS) and ERA. European Research Advisory Board Final Report.

Ford Foundation (2011). About Ford Foundation. New York: Ford Foundation.

Gauger, Jörg-Dieter, and Josef. 2010. Empirische Bildungsforschung. Berlin: Konrad Adenauer Stiftung.

Green, Andy. 1997. Education, Globalization, and the Nation State. New York: Macmillan.

Institute of Education Science (IES). 2008. Rigor and Relevance: Director's Biennial Report to Congress. Washington, DC: IES, U.S. Department of Education.

Iqbal, Javed. 2010. "Role of Non-governmental Organization for the Development of Basic Education in Punjab, Pakistan.” Educational Research and Review 5 (8): 423-426.

Jencks, Christopher, Marshall Smith, Henry Acland, Mary J. Bane, David Cohen, and Herbert Gintis. 1972. Inequality: A Reassessment of the Effect of Family and Schooling in America. New York: Basic Books.

Jun, Jong S. 1986. Public Administration: Design and Problem Solving. New York: Macmillan Publishing Company.

Kadzamira, Esme, and Demis Kunje. 2002. The Changing Roles of Non-Governmental Organizations in Education in Malawi. Zomba, Malawi: Centre for Educational Research and Training at University of Malawi.

Kaestle, Carl F. 1993. "The Awful Reputation of Education Research.” Educational Researcher 22 (1): 26-31.

Konrad Adenauer Stiftung (KAS). 2012. Annual Report 2011. Berlin: Konrad Adenauer Stiftung.

Kramer, Ralph M. 1987. "Voluntary Agencies and Personal Social Services.” In The Nonprofit Sector: A Research Handbook, edited by W. W. Powell (pp. 240-257). New Haven, CT: Yale University Press.

Lagemann, Ellen C. 2000. An Elusive Science: The Troubling History of Education Research. Chicago: University of Chicago Press.

Lauder, Hugh. 2006. Education, Globalization, and Social Change. Oxford, UK; New York: Oxford University Press.

Loeb, Susanna, and Marianne E. Page. 2000. "Examining the Link between Teachers' Wages and Students' Outcomes: The Importance of Alternative Labor Market Opportunities and Nonpecuniary Variation.” Review of Economics and Statistics 82 (3): 393-408.

Mitchell, Theodore R., and Analee Haro. 1999. "Poles Apart: Reconciling the Dichotomies in Education Research.” In Issues in 
Education Research, edited by Ellen C. Lagemann and Lee S. Shulman (pp. 42-62). San Francisco, CA: Jossey-Bass.

National Academies. 2011. Our Study Process: Ensuring Independent, Objective Advice. Washington, DC: National Academies.

National Board of Education Science. 2011. 2011 Annual Report. Washington, DC: IES.

National Research Council (NRC). 1958. A Proposed Organization for Research in Education. Washington, DC: National Academy of Sciences.

NRC. 1977. Fundamental Research and the Process of Education. Washington, DC: National Academy of Sciences.

NRC. 1986. Creating a Center for Education Statistics: A Time for Action. Washington, DC: National Academy of Sciences.

NRC. 1992. Research and Education Reform: Roles for the Office of Educational Research and Improvement. Washington, DC: National Academies Press.

NRC. 1999. Improving Student Learning: A Strategic Plan for Education Research and Its Utilization. Washington, DC: National Academies Press.

NRC. 1992. Research and Education Reform: Roles for the Office of Educational Research and Improvement. Washington, DC: National Academy of Sciences.

NRC. 2001. Science, Evidence, and Inference in Education: Report of a Workshop. Washington, DC: National Academy Press.

NRC. 2002. Scientific Research in Education. Washington, DC: National Academies Press.

NRC. 2003. Strategic Education Research Partnership. Washington, DC: National Academies Press.

NRC. 2004. Strengthening Peer Review in Federal Agencies That Support Education Research. Washington, DC: National Academies Press.

NRC. 2011. The Importance of Common Metrics for Advancing Social Science Theory and Research: A Workshop Summary. Washington, DC: National Academies Press.

Organisation for Economic and Co-operative Development (OECD). 1995. Educational Research and Development: Trends, Issues, and Challenges. Paris: OECD.

President's Commission on School Finance. 1971. Progress Report of the President's Commission on School Finance. ERIC No. ED058643. Washington, DC: President's Commission on School Finance.

PREST. 2002. A Comparative Analysis of Public, Semi-Public and Recently Privatised Research Centres. PREST Final Project Report (CBSTII contract ERBHPV2-CT-200-01). Manchester, UK: PREST.

Research Assessment Exercise (RAE). 2009. RAE 2008 UOA 45 Education Subject Overview Report. London: RAE.
RAND. 2011. RAND's Standards for High-Quality Research and Analysis. Los Angeles, CA: RAND Corporation.

Rockefeller Foundation. 2011. Rockefeller Foundation. New York: Rockefeller Foundation.

Rutter, Michael. 1982. Fifteen Thousand Hours: Secondary Schools and Their Effects on Children. Cambridge, MA: Harvard University Press.

Sroufe, Gerald E. 1997. “Improving the 'Awful Reputation' of Education Research.” Educational Researcher 26 (7): 26-28.

Stedman, Lawrence C. 1985. “A New Look at the Effective Schools Literature.” Urban Education 20 (3): 295-326.

Stokes, Donald E. 1997. Pasteur's Quandrant: Basic Science and Technological Innovation. Washington, DC: Brookings Institution Press.

Taylor, William. 1972. "Retrospect and Prospect in Educational Research.” Educational Research 15: 3-9.

Tooley, James. 1998. Educational Research: A Critique. London: OFSTED.

Western Australian Institutes for Educational Research (WAIER). 2012. Brief History of Western Australian Institutes for Educational Research. Sydney: WAIER.

Spivak, Gayatri C. 2012. An Aesthetic Education in the Era of Globalization. Cambridge, MA: Harvard University Press. 